\title{
Effect of Feeding Different Levels of Corn Silage on Milk Yield and Quality in Dairy Assaf Ewes
}

\author{
Ahmed Zaazaa ${ }^{1}$, Mohammed Sabbah², Tawfiq Qubbaj ${ }^{3}$ and Jamal Abo Omar ${ }^{1, *}$ \\ ${ }^{I}$ Department of Animal Production, An-Najah National University, Nablus, Palestine \\ ${ }^{2}$ Department of Nutrition and Food Technology, An-Najah National University, Nablus, Palestine \\ ${ }^{3}$ Department of Plant Production and Protection, An-Najah National University, Nablus, Palestine
}

('Corresponding author’s e-mail: aboomar57@najah.edu)

Received: 18 October 2020, Revised: 2 June 2021, Accepted: 18 June 2021

\begin{abstract}
This study aimed to investigate the impact of feeding by different corn silage (CS) proportions on ewes milk yield and fatty acids composition. Twenty-one lactating Assaf ewes were divided into 3 groups (7 ewes each). The following dietary treatments based on increasing the proportion of CS in the total mixed ratio (TMR) were tested; (1) $47 \% \mathrm{AH}(0 \% \mathrm{CS}$ in the TMR) correspond to $0 \% \mathrm{CS}$, (2) $23.5 \%$ $\mathrm{AH}(23.5 \% \mathrm{CS}$ in the TMR) correspond to $50 \% \mathrm{CS}$, and (3) $0 \% \mathrm{AH}$ (47\% CS in the TMR) correspond to $100 \% \mathrm{CS}$. After 8 weeks of feeding, the type of diet had no significant effect on milk yield and solid; however, it significantly affects the milk fat. The levels of C8:0 and C14:0 were not affected by different silage levels. While the C10:0 and C12:0 significantly increased when fed on a 100\% CS diet. However, a significantly lower level of C16:0 (33.22\%) was observed in the $100 \% \mathrm{CS}$ compared to feeding on silage at 50 and $0 \%$ (40.66 and $37.98 \%$, respectively). Similar trend was observed for C18:0, the lowest was in $100 \%$ CS compared with the different feeding diets $(7.52,12.69,10.61 \%$ for $100,50,0 \%$, respectively). Total USFA in milk were decreased $(p<0.05)$ by feeding 100 and $50 \%$ CS compared to 0 $\%$ CS feeding. It can be concluded that the replacement of alfalfa with CS had some influence on milk composition, especially the fatty acids profile.
\end{abstract}

Keywords: Corn silage, Alfalfa hay, Milk yield, Fatty acids profile, Assaf

\section{Introduction}

The main source of feed for dairy sheep is pastures, especially during lactation. However, indoor feeding is practiced in many countries in the Middle East. Other sources of feeds are used in dairy sheep feeding as the productivity of pastures is variable. Hay, silage, and concentrates are the main feeds used in large dairy sheep operations with high milk production [1]. Corn (Zea mays) whole-plant silage is an important feed ingredient in lactating ruminants in many world regions [2]. Compared to legumes, corn silage (CS) contains higher amounts of starch, making it an interesting means to improve ruminants' general performance by reducing the feed energy lost in methanogenesis. The fat content and the fatty acid profile of milk depend on diet composition, animal and environment [3] and are largely influenced by pasture plants. CS and corn grains have a low concentration of fatty acids (FA). However, because of their high inclusion rate in lactating ruminant diets, they contribute substantially to total unsaturated fatty acids (UFA) intake. The predominant long-chain FA in corn silage is commonly reported to be C18:2. It is recommended to reduce the unsaturated fatty acids $(\mathrm{C} 18: 2)$ in the rumen to minimize the risk of biohydrogenation induced milk fat depression [4]. Several studies have shown that milk and dairy products are the major sources of saturated fatty acids (SFA) in the human diet $[5,6]$, where dairy products remain an important source of FA of nutritional interest in human nutrition, especially conjugated linoleic acid and omega-3 [7]. The diet of ruminants can alter the composition of milk fatty acids [8]. It is interesting to control the diet of the ewe in order to improve the nutritional composition of milk fatty acids. The composition of milk can be considerably modified by changes in the diet, among which the fat content and fatty acid profile are the most variable and sensitive to changes in diet [9-11]. Replacing alfalfa hay (AH) with CS in the diet would increase dietary starch supply and improve the ruminal environment, which would enhance the animals' performance (i.e., lower ruminal $\mathrm{pH}$ and acetate: propionate ratio) less favourable to methanogenesis, which would result in lower $\mathrm{CH}_{4}$ energy losses in 
dairy cows. Therefore, the objective of this study was to determine the effects of replacing AH with CS in lactating Assaf ewes' diets on feed intake, milk production, milk quality, and milk fatty acid profile.

\section{Materials and methods}

This study was conducted at the dairy farm of the Faculty of Agriculture and Veterinary Medicine, Tulkarm, Palestine. The project was conducted after the approval of the Institutional Animal Care Committee of An Najah National University.

Silage samples were collected from private corn (Zea mays L.) field at about $36 \%$ DM by cutting plants with a power cutter and chopping with a chipper/shredder before inoculation with silage fermentation additive and packing in $20 \mathrm{~L}$ plastic barrels. The barrels were sealed with an air-tight lid and placed in storage for $42 \mathrm{~d}$. After the ensiling period, a sample from each barrel was collected, dried in an oven at $40{ }^{\circ} \mathrm{C}$ for $48 \mathrm{~h}$ and ground to $1 \mathrm{~mm}$.

Table 1 Composition of corn silage (CS) used in the experiment.

\begin{tabular}{cc}
\hline Parameter & \% \\
\hline DM & 36.0 \\
\hline OM & 93 \\
\hline Crude protein & 10.9 \\
\hline NDF & 50.0 \\
\hline ADF & 28.0 \\
\hline EE & 2.70 \\
\hline pH & 3.60 \\
\hline Lactic acid & 3.30 \\
\hline Propionic acid & 0.15 \\
\hline Butyric acid & 0.24 \\
\hline Ammonia & 1.11 \\
\hline Water soluble carbohydrates & 1.98 \\
\hline Total FA & 2.31 \\
\hline C18:2 & 1.19 \\
\hline & \\
\hline C16:0 & 15.90 \\
\hline C18:1 $18: 2$ & 18.60 \\
\hline C18:3 & 51.50 \\
\hline
\end{tabular}

\section{Ewes, experimental design, and diets}

Twenty-one lactating Assaf ewes were divided into 3 groups, with 7 ewes in each. The ewes were of average body weight of $64 \pm 3 \mathrm{~kg} / \mathrm{d}$ and milk yield of $2.5 \pm 0.2 \mathrm{~kg} / \mathrm{d}$. The experimental treatments were based on increasing the proportion of the TMR (47:53 forage (alfalfa hay: concentrate ratio, DM basis) to replace alfalfa hay (AH). The dietary treatments were (1) $47 \% \mathrm{AH}$ (0\% CS in the TMR), (2) $23.5 \% \mathrm{AH}$ (23.5\% CS in the TMR), and (3) $0 \%$ AH (47\% CS in the TMR) Table 2.

Ewes were housed in individual pens and had free access to drinking water. Feed consumption was recorded daily by weighing feeds offered to and refused by the ewes. Samples of the rations, ingredients, and refusals were collected daily and kept for later analysis. Composited samples of feed were ground to pass a 1-mm screen using a Wiley mill (standard model 4; Arthur M. Thomas Co., Philadelphia, PA) and analyzed for dry matter (DM), crude protein (CP), neutral detergent fiber (NDF), acid detergent fiber (ADF), ether extract (EE), and GE. Samples of CS were analyzed for ethanol, lactic acid, volatile fatty acids (VFA), ammonia $\mathrm{N}$, and water-soluble carbohydrates.

\section{Chemical analyses for feed}

CS (Table 1) and the experimental diets were analyzed (three samples from each ration) according to procedures of AOAC [12] for DM $\left(105{ }^{\circ} \mathrm{C}\right.$ in a forced air oven for $24 \mathrm{~h}$ ), organic matter (ash; weight retained upon ashing at $550^{\circ} \mathrm{C}$ for $8 \mathrm{~h}$; \#942.05), N (\#976.06) and ether extract (EE; Soxhlet procedure, 
Soxtec System, TECATOR, Hoganas, Sweden; \#920.29). Additionally, samples were analyzed for neutral detergent fiber (aNDF; with use of a heat-stable amylase and sodium sulphite in the ND) and acid detergent fiber (ADF; ANKOM 2000 fiber analyzer, ANKOM Technology Corporation, Macedon, NY, USA) according to Van Soest et al. [13], (Table 2). Values for aNDF and ADF are expressed inclusive of residual ash. The ME values were calculated based on NRC [14] feed composition tables.

Silage extracts were analyzed for water-soluble carbohydrates [15], lactic acid ([16], and for ethanol using GLC (model 6850; Agilent Technologies Canada Inc., Mississauga, ON, Canada).

Table 2 Composition of the experimental diets.

\begin{tabular}{|c|c|c|c|}
\hline Group & $0 \% \mathrm{CS}$ & $50 \% \mathrm{CS}$ & $100 \% \mathrm{CS}$ \\
\hline Concentrate & 53 & 53 & 53 \\
\hline $\mathrm{CS}$ & 0 & 23.5 & 47 \\
\hline $\mathrm{AH}$ & 47.0 & 23.5 & 0 \\
\hline \multicolumn{4}{|c|}{ Chemical analysis (DM basis) } \\
\hline DM & 54.0 & 64.4 & 84.5 \\
\hline $\mathrm{CP}$ & 14.0 & 14.0 & 15.0 \\
\hline $\mathrm{ADF}$ & 11.0 & 14.0 & 16.0 \\
\hline aNDF & 27.0 & 22.0 & 21.0 \\
\hline Ash & 5.0 & 5.7 & 6.7 \\
\hline $\mathrm{Ca}$ & 1.21 & 1.15 & 1.15 \\
\hline $\mathrm{P}$ & 0.64 & 0.70 & 0.68 \\
\hline $\mathrm{ME}(\mathrm{kcal} / \mathrm{kg})$ & 2780 & 2800 & 2810 \\
\hline Fat & 3.2 & 3.1 & 3.4 \\
\hline \multicolumn{4}{|l|}{$\mathrm{g} / 100 \mathrm{~g}$ of FA } \\
\hline $\mathrm{C} 16: 0$ & 16.2 & 20.0 & 19.5 \\
\hline $\mathrm{C} 16: 1$ & 0.56 & 1.2 & 1.25 \\
\hline C18:0 & 4.4 & 11.1 & 10.5 \\
\hline C18:1 trans & 0.45 & 0.98 & 1.08 \\
\hline $\mathrm{C} 18: 1 \mathrm{cis}$ & 27.4 & 28.5 & 28.0 \\
\hline $\mathrm{C} 18: 2$ & 40.0 & 29.1 & 31.3 \\
\hline C18:3 & 4.0 & 3.9 & 4.0 \\
\hline Others & 7.5 & 6.9 & 6.8 \\
\hline
\end{tabular}

Composition per $1 \mathrm{~kg}$ contained, yellow corn, $600 \mathrm{~g} / \mathrm{kg}$; soybean meal, $269 \mathrm{~g} / \mathrm{kg}$; wheat bran, $100 \mathrm{~g} / \mathrm{kg}$; ammonium chloride, $3 \mathrm{~g} / \mathrm{kg}$; dicalcium phosphate, $6 \mathrm{~g} / \mathrm{kg}$; limestone, $17 \mathrm{~g} / \mathrm{kg}$; NaCl, $3 \mathrm{~g} / \mathrm{kg}$; premix, 1 $\mathrm{g} / \mathrm{kg}$ (Composition per $1 \mathrm{~kg}$ contained, vitamin A, $2000000 \mathrm{IU}$; vitamin D3, $40000 \mathrm{IU}$; vitamin E, 400 IU; Mn, $12.8 \mathrm{mg}$; Zn, $9.0 \mathrm{mg}$; I, $1.56 \mathrm{mg}$; Fe, $6.42 \mathrm{mg}$; Co, $50 \mathrm{mg}$; Se, 32mg plus an antioxidant); soap stock, $1 \mathrm{~g} / \mathrm{kg}$. 


\section{Milk quantity and quality}

Ewes were milked twice daily at 6:00 am and 6:00 pm in their pens, and milk production was recorded per milking during the entire feeding trial that lasted for $60 \mathrm{~d}$. Milk samples were collected in a sterile container from each ewe at each milking, stored at $4{ }^{\circ} \mathrm{C}$ for later analysis. All samples were sent to the laboratory for chemical analysis (Department of Nutrition and Food Technology, at An-Najah National University, Palestine), to be conducted on the same day of collection. Milk composition (fat, SNF, density, protein, lactose, solids, and freezing point) was evaluated automatically using a milk analyzer (MilkoScope Julie C8 Automatic, ScopeElectric $\AA$, Regensburg, German), according to the manufacturer instructions. Milk pH was analyzed by using calibrated $\mathrm{pH}$ meter.

\section{Milk fat extraction and GC analysis}

Fat extraction and collection were according to the AOAC 989.05. $50 \mathrm{~mL}$ of a milk sample from each treatment were first digested with $10 \mathrm{~mL} \mathrm{NH}_{4} \mathrm{OH} 58 \%$ and fat extracted from the residue by diethyl and petroleum ether $(1: 1)$. The collected fat was kept at $-18{ }^{\circ} \mathrm{C}$ for the FA profile analysis.

\section{Statistical analysis}

The collected data were analyzed by using JMP software 8.0 (SAS Institute, Cary, NC, USA, 1989) [17], 2-way ANOVA, and the least significant difference test for mean comparisons were used. Differences were considered to be significant at $p<0.05$.

\section{Results and discussion}

\section{Corn silage and experimental diets chemical composition}

The chemical analysis and fatty acid profile of CS are presented in Table 1. The total FA as a percent of DM was $2.31 \%$, while the percent of the FA C16:0, C18:1, C18:2 and C18:3 was 15.9, 18.6, 51.5 and 7.3 $\%$, respectively. The content of dry and mineral matter, proteins, lipids, and fatty acids of different diets are shown in Table 2. The amounts of dietary fatty acids varied according to the proportion of CS in feed ingredients for each Assaf ewes group. The mineral matter was the same in all dietary treatments (5.0, 5.7, $6.7 \%$ for $0,50,100 \%$ CS diet, respectively). Diets with 50 and $100 \%$ CS had higher levels of FA C16:0, C16:1 and C18:0 (Table 2). However, type of forage (AH, CS) had no effects on C18:1-cis, and C18:3. While, as the total replacement of corn silage increased in the feed tested group, it has been associated with an increased DM and AFD . Conversely, the NDF was found to decrease.

The CS total FA as a percent of DM was 2.31 (Table 1), while the percent of the FA C16:0, C18:1, C18:2 and C18:3 was 15.9, 18.6, 51.5 and $7.3 \%$, respectively. Little information available about FA profiles for the whole corn plant silage as most research dealt with grains of various corn strains. Generally, CS and corn grain are characterized as low fatty acids concentrated plants (18). However, the high inclusion rate in diets, corn contributes greatly to unsaturated FA intake [18].

\section{Milk yield}

Daily milk production for the different CS replacement ratio feed treatment groups were measured during this study. Type of diet had no significant effect on milk yield. The average daily milk yield ranged from 2.49 to $2.78 \mathrm{~kg} / \mathrm{d}$. Ewes fed the $100 \%$ CS produced more milk $(2.78 \mathrm{~kg} / \mathrm{d})$ compared to 2.6 and $2.49 \mathrm{~kg} / \mathrm{d}$ from ewes fed 50 and $0 \% \mathrm{CS}$, respectively.

\section{Milk quality and compositions and pH}

Milk $\mathrm{pH}$ increased $(p<0.05)$ when CS was partially or totally replaced by alfalfa hay starting from the third week of the trial (Table 3). Complete replacement of alfalfa with CS resulted in a significant increase in milk fat. This increase started after the $7^{\text {th }}$ week of the feeding trial (Table 3). Similar milk fat content was observed in milk of ewes fed alfalfa as total or partially replaced by CS. Results of this study showed that diet ingredient composition had no effect on the milk SNF, density, protein, lactose, solids, and freezing point.

The fatty acid profile of ewes' milk is shown in Table 4. The levels of C8:0 and C14:0 were not affected by silage levels. While the $100 \% \mathrm{CS}$ diet increased $(p<0.05) \mathrm{C} 10: 0$ and C12:0 compared to the other dietary groups. However, diets had significant effects $(p<0.05)$ on C16:0 and C18:0. The lowest level of C16:0 (33.22\%) was observed when feeding the $100 \%$ CS compared to that when feeding silage at levels of 50 and $0 \%$ (40.66 and $37.98 \%$, respectively). A similar trend was observed in $100 \%$ CS where levels of $\mathrm{C} 18: 0$ were the lowest among the different feeding diets $(7.52,12.69,10.61 \%$ for 100 , 50, $0 \%$, respectively) Table 4. The level of CS had no effect on C18:1 trans and C18:2. However, the 
level of C18:1 cis was the lowest $(p<0.05)$ in the milk of ewes fed the $100 \%$ CS. Total USFA in milk was decreased $(p<0.05)$ by feeding 100 and $50 \%$ CS compared to $0 \%$ CS feeding (Table 4). Type of diets had no effect on milk total SFA. The concentrations of SFA were $76.31,75.89$, and $73.7 \%$ of milk from ewes fed the 0,50 and $100 \% \mathrm{CS}$, respectively (Table 4).

The results of this study showed that diet ingredient composition did not affect milk density. However, Belabbes et al. [19] reported a significant effect on density in the milk of ewes consuming different diets with varying levels of concentrate.

Diets had no significant effect on the freezing point. In contrast, the type of diet caused significant differences in ewes' milk freezing point under different forage levels [19]. Diets did not affect the major components of milk. Similar trends were observed by Bellabes [19]; forage type had no effects on milk protein. However, lactose, the main component of milk dry matter, was the least affected by the type of diet $[20,21]$.

Sheep milk has high levels of protein, fat, minerals, and vitamins compared with milks of cow [22] and contains conjugated linoleic acid, oleic acid, and vaccenic acid [23-25]. Increasing the grass levels in diets had significant improvement of milk fat and protein levels [26].

Our results showed that the type of diet had an overall effect on fatty acids in sheep's milk, which is agreed with the results of $[27,28]$. At the same time, some researchers have shown that the diet does not affect the proportion of some fatty acids such as C14: 0 and C16: 0 .

Milk fat and quality are influenced by the type of diet [29,30]. Conserved and processed forages affect milk composition, but this effect is lower than natural pastures [31-33].

The levels of C8:0 and C14:0 were not affected by silage levels. In comparison, the $100 \% \mathrm{CS}$ diet increased levels of $\mathrm{C} 10: 0$ and $\mathrm{C} 12: 0$ compared to the other dietary groups. However, diets had significant effects on $\mathrm{C} 16: 0$ and $\mathrm{C} 18: 0$. The lowest level of C16:0 (33.22 \%) was observed when feeding the $100 \%$ $\mathrm{CS}$ compared to that when feeding silage at levels of 50 and $0 \%$ (40.66 and $37.98 \%$, respectively). A similar trend was observed in $100 \%$ CS where levels of C18:0 were the lowest among the different feeding diets $(7.52,12.69,10.61 \%$ for $100,50,0 \%$, respectively).

The level of CS did not affect C18:1 trans and C18:2. However, the level of C18:1 cis was the lowest $(p<0.05)$ in the milk of ewes fed the $100 \%$ CS. Total USFA in milk was decreased $(p<0.05)$ by feeding 100 and $50 \%$ CS compared to $0 \%$ CS feeding.

Type of diets did not affect milk total SFA. The concentrations of SFA were 76.31, 75.89, and 73.7 $\%$ of milk from ewes fed the 0,50 and $100 \%$ CS, respectively (Table 3 The differences in FA content are associated with forage processing [34]. The ensiling process reduced the PUFA in silage via lipolysis and oxidation during the ensiling and drying process [34]. It could also be attributed to the complex fermentation process in the ensiling process.

The most abundant SFA was palmitic acid (C16:0), followed by stearic acid (C14), then the myristic acid (C18:0). These results are partially agreed by previous research where the values of palmatic were the highest, followed myrestic acid and stearic acid [18].

Results of this study also showed that forage type did not have a significant effect on the SF. The processing method (ensiling, haymaking) resulted in significant changes in the total amount of cis-MUFA but not the trans-isomers. Similarly, Baldin et al. [18] reported that the processing of forage led to changes in the total amount of trans-MUFA.

In the current study, milk from sheep-fed AH showed $25 \%$ more cis-c18:1 than $100 \% \mathrm{CS}$. However, the trans- c18:1 had similar values. Type of forage had a similar effect on the C18:2. Type of diet had no modification on PUFA; however, previous research showed that the conserved forage type used for sheep feeding modified the total PUFA content [19]. 
Table 3 Effect of different corn silage (CS) levels on milk composition of sheep Assaf ewes.

\begin{tabular}{|c|c|c|c|c|c|c|}
\hline & \multirow{2}{*}{$\begin{array}{l}\text { CS } \\
(\%)\end{array}$} & \multicolumn{5}{|c|}{ Milking (weeks) } \\
\hline & & $\mathbf{0}$ & 2 & 4 & 6 & 8 \\
\hline \multirow{3}{*}{$\begin{array}{l}\text { Fat } \\
(\%)\end{array}$} & 0 & $5.60 \pm 0.14$ & $5.63 \pm 0.16$ & $5.66 \pm 0.17$ & $5.69 \pm 0.19$ & $5.76 \pm 0.19$ \\
\hline & 50 & $5.63 \pm 0.12$ & $5.70 \pm 0.15$ & $5.78 \pm 0.17$ & $5.86 \pm 0.17$ & $5.93 \pm 0.16^{\mathrm{a}}$ \\
\hline & 100 & $5.68 \pm 0.13$ & $5.80 \pm 0.09$ & $5.89 \pm 0.05$ & $5.96 \pm 0.09$ & $6.07 \pm 0.10^{\mathrm{a}, \mathrm{b}}$ \\
\hline \multirow{3}{*}{ SNF (\%) } & 0 & $9.70 \pm 0.14$ & $9.74 \pm 0.11$ & $9.72 \pm 0.07$ & $9.78 \pm 0.12$ & $9.80 \pm 0.10$ \\
\hline & 50 & $9.75 \pm 0.13$ & $9.79 \pm 0.10$ & $9.80 \pm 0.08$ & $9.83 \pm 0.08$ & $9.88 \pm 0.07$ \\
\hline & 100 & $9.74 \pm 0.18$ & $9.79 \pm 0.11$ & $9.79 \pm 0.12$ & $9.79 \pm 0.11$ & $9.82 \pm 0.11$ \\
\hline \multirow{3}{*}{ Density } & 0 & $33.63 \pm 1.03$ & $32.74 \pm 0.50$ & $32.68 \pm 0.97$ & $32.60 \pm 0.63$ & $33.02 \pm 0.70$ \\
\hline & 50 & $32.50 \pm 0.75$ & $32.55 \pm 0.72$ & $32.38 \pm 0.53$ & $32.74 \pm 0.78$ & $32.43 \pm 0.62$ \\
\hline & 100 & $32.15 \pm 0.68$ & $32.58 \pm 0.32$ & $32.32 \pm 0.78$ & $32.54 \pm 0.66$ & $31.89 \pm 0.71$ \\
\hline \multirow{3}{*}{$\begin{array}{c}\text { Protein } \\
(\%)\end{array}$} & 0 & $3.53 \pm 0.02$ & $3.55 \pm 0.02$ & $3.55 \pm 0.02$ & $3.55 \pm 0.02$ & $3.56 \pm 0.01$ \\
\hline & 50 & $3.54 \pm 0.03$ & $3.56 \pm 0.02$ & $3.56 \pm 0.01$ & $3.57 \pm 0.02$ & $3.57 \pm 0.01$ \\
\hline & 100 & $3.54 \pm 0.03$ & $3.56 \pm 0.01$ & $3.56 \pm 0.01$ & $3.56 \pm 0.02$ & $3.57 \pm 0.02$ \\
\hline \multirow{3}{*}{$\begin{array}{c}\text { Lactose } \\
(\%)\end{array}$} & 0 & $5.42 \pm 0.11$ & $5.42 \pm 0.07$ & $5.41 \pm 0.05$ & $5.43 \pm 0.07$ & $5.46 \pm 0.07$ \\
\hline & 50 & $5.44 \pm 0.10$ & $5.47 \pm 0.08$ & $5.46 \pm 0.06$ & $5.48 \pm 0.07$ & $5.52 \pm 0.07$ \\
\hline & 100 & $5.44 \pm 0.11$ & $5.45 \pm 0.09$ & $5.45 \pm 0.12$ & $5.45 \pm 0.11$ & $5.45 \pm 0.10$ \\
\hline \multirow{3}{*}{$\begin{array}{c}\text { Solids } \\
(\%)\end{array}$} & 0 & $0.75 \pm 0.03$ & $0.76 \pm 0.03$ & $0.76 \pm 0.03$ & $0.77 \pm 0.04$ & $0.77 \pm 0.05$ \\
\hline & 50 & $0.76 \pm 0.02$ & $0.77 \pm 0.02$ & $0.78 \pm 0.01$ & $0.77 \pm 0.01$ & $0.78 \pm 0.02$ \\
\hline & 100 & $0.75 \pm 0.01$ & $0.78 \pm 0.02$ & $0.77 \pm 0.02$ & $0.78 \pm 0.01$ & $0.80 \pm 0.01$ \\
\hline \multirow{3}{*}{ F.P $\left({ }^{\circ} \mathrm{C}\right)$} & 0 & $-0.63 \pm 0.03$ & $-0.63 \pm 0.03$ & $-0.64 \pm 0.02$ & $-0.63 \pm 0.03$ & $-0.64 \pm 0.02$ \\
\hline & 50 & $-0.61 \pm 0.04$ & $-0.62 \pm 0.02$ & $-0.62 \pm 0.02$ & $-0.63 \pm 0.02$ & $-0.63 \pm 0.03$ \\
\hline & 100 & $-0.63 \pm 0.03$ & $-0.63 \pm 0.03$ & $-0.63 \pm 0.04$ & $-0.63 \pm 0.02$ & $-0.63 \pm 0.03$ \\
\hline
\end{tabular}

"a" The mean value is significant different compering to the control at 0 week at the same level of corn silage $(p<0.05)$. " $\mathrm{b}$ " The mean value is significant different compering to the same week at $0 \%$ corn silage $(p<0.05)$. 
Table 4 Effect of different corn silage (CS) levels on the fatty acid profile of sheep Assaf ewes.

\begin{tabular}{cccc}
\hline \multirow{2}{*}{ Fatty acid (\%) } & \multicolumn{3}{c}{ Corn silage level (\%) } \\
\cline { 2 - 4 } & $\mathbf{0} \% \mathbf{C S}$ & $\mathbf{5 0} \% \mathbf{C S}$ & $\mathbf{1 0 0} \% \mathbf{C S}$ \\
\hline C8:0 & $2.07 \pm 0.40$ & $1.61 \pm 0.33$ & $2.12 \pm 0.60$ \\
C10:0 & $7.87 \pm 1.59$ & $6.71 \pm 0.94$ & $10.98 \pm 1.29^{\mathrm{a}}$ \\
C12:0 & $4.31 \pm 1.38$ & $2.89 \pm 0.63$ & $5.65 \pm 0.27^{\mathrm{a}}$ \\
C14:0 & $13.55 \pm 1.87$ & $11.33 \pm 1.57$ & $14.21 \pm 1.32$ \\
C16:0 & $37.98 \pm 2.63$ & $40.66 \pm 2.78$ & $33.22 \pm 2.76^{\mathrm{a}}$ \\
C18:0 & $10.61 \pm 0.66$ & $12.69 \pm 1.38$ & $7.52 \pm 0.98^{\mathrm{a}}$ \\
\hline Sum SFA & $76.31 \pm 8.53$ & $75.89 \pm 7.63$ & $73.7 \pm 7.13$ \\
\hline C16:1 & 0 & 0 & 0 \\
C16:1 & 0 & 0 & $1.65 \pm 0.90$ \\
C18:2 & $1.46 \pm 0.18$ & $1.45 \pm 0.21$ & $17.75 \pm 0.18^{\mathrm{a}}$ \\
C18:1 Cis & $23.87 \pm 1.30$ & $23.14 \pm 1.33$ & $3.95 \pm 0.87$ \\
C18:1Tranc & $3.47 \pm 0.32$ & $4.22 \pm 1.02$ & $23.35 \pm 1.95$ \\
\hline Sum USFA & $28.8 \pm 1.8$ & $24.81 \pm 2.74$ &
\end{tabular}

"a" Mean value in the same row are significant different comparing to the control $(p<0.05)$.

\section{Conclusions}

Processed forages can be used as a cheap feed source when other sources of feed as pastures is limited throughout the year. However, some advantages could be achieved regarding milk quality and yield. Our achievement by using the low-cost alternative to diet supplementation strategies using corn silage replacement of alfalfa. The replacement of alfalfa with CS positively influenced milk composition, especially the fatty acids profile. Therefore the results could contribute to offering a low-cost alternative way for producing different dairy products with a fatty acid profile suitable for human health, which is a great interesting aspect to the food industries and livestock sector, especially in developing countries where feeding cost is the main challenge facing the livestock husbandry

\section{Acknowledgements}

We thank Care International (CARE Palestine) Building 48, $1^{\text {st }}$ floor, Tireh Street, Ramallah P.O. Box 54258, Jerusalem 91541, Israel through the SOUQUNA project.

\section{References}

[1] G Molle, M Decandia, A Cabiddu, LS Yan and A Cannas. An update on the nutrition of dairy sheep grazing Mediterranean pastures. Small Ruminant Res. 2008; 77, 93-112.

[2] TJ Klopfenstein, GE Erickson and LL Berger. Maize is a critically important source of food, feed, energy and forage in the USA. Field Crop. Res. 2013; 153, 5-11.

[3] G Pulina, A Nudda, G Battacone and A Cannas. Effects of nutrition on the contents of fat, protein, somatic cells, aromatic compounds, and undesirable substances in sheep milk. Anim. Feed Sci. Tech. 2006; 131, 255-91.

[4] T Jenkins. Managing the rumen environment to control milk fat depression. In: Proceedings of the Penn State Dairy Nutrition Workshop, Grantville PA, 2011, p. 31-7. 
[5] B Bates, A Lennox, A Prentic and C Bates. National diet and nutrition survey; results from years 1, 2, 3 and 4 (combined) of the rolling programme (2008/2009 - 2011/2012). London, 2014.

[6] KF Hulshof, MAV Erp-Baart, M Anttolainen, W Becker, SM Church, C Couet, E Hermann-Kunz, H Kesteloot, T Leth, I Martins, O Moreiras, J Moschandreas, L Pizzoferrato, AH Rimestad, H Thorgeirsdottir, JMV Amelsvoort, A Aro, AG Kafatos, D Lanzmann-Petithory and GV Poppel. Intake of fatty acids in Western Europe with emphasis on trans fatty acids: The transfair study. Eur. J. Clin. Nutr. 1999; 53, 143-57.

[7] C Hurtaud, C Agabriel, M Dutreuil and B Rouille. Characterization composition of milks according to feeding practices in the main French dairy regions. Res. Ruminants. 2010; 17, 381-4.

[8] MD Renobales, G Amores, J Arranz, M Virto, LJR Barrón, MA Bustamante, JCRD Gordoa, AI Nájera, I Valdivielso, E Abilleira, IBD Heredia, FJ Pérez-Elortondo, R Ruiz, M Albisu and N Mandaluniz. Part-time grazing improves sheep milk production and its nutritional characteristics. Food Chem. 2012; 130, 90-6.

[9] JD Sutton. Altering milk composition by feeding. J. Dairy Sci. 1989; 72, 2801-14.

[10] TC Jenkins and MA McGuire. Major advances in nutrition: Impact on milk composition. J. Dairy Sci. 2006; 89, 1302-10.

[11] BH Schwendel, TJ Wester, PCH Morel, MH Tavendale, C Deadman, NM Shadbolt and DE Otter. Invited review: Organic and conventionally produced milk - an evaluation of factors influencing milk composition. J. Dairy Sci. 2015; 98, 721-46.

[12] Association of Official Analytical Chemists. Official methods of analysis association of official analytical chemists. $15^{\text {th }}$ ed. Association of Official Analytical Chemists, Virginia, 1990.

[13] PJV Soest, JP Robertson and BA Lewis. Methods for dietary fiber, neutral detergent fiber, and non starch polysaccharides in relation to animal nutrition. J. Dairy Sci. 1991; 74, 3583-97.

[14] National Research Council. Nutrient Requirements of Sheep. $6^{\text {th }}$ ed. National Academy Press, Washington DC, 1985.

[15] M DuBois, KA Gilles, JK Hamilton, PA Rebers and F Smith. Colorimetric method for determination of sugars and related substances. Anal. Chem. 1956; 28, 350-6.

[16] KA Taylor. A simple colorimetric assay for muramic acid and lactic acid. Appl. Biochem. Biotechnol. 1996; 56, 49-58.

[17] Statistical Analysis System Institute. SAS/STATTM user's guide: Statistics. $4^{\text {th }}$ ed. Cary, North Carolina, 1989.

[18] M Baldin, Y Ying, Y Fan, G Roth, DP Casper and KJ Harvatine. Characterization of linoleic acid (C18:2) concentration in commercial corn silage and grain hybrids. Dairy Sci. 2018; 101, 222-32.

[19] M Belabbes, K Bouderoua, S Attou and A Homrani. Diets of ewes improve fatty acid composition of milk. Adv. Biores. 2018; 9, 18-25.

[20] N Sahan, D Say and A Kacar. Changes in chemical and mineral contents of Awassi ewe's milk during lactation. Turk. J. Vet. Anim. Sci. 2005; 29, 589-93.

[21] EM Anifantakis. Comparison of the physico-chemical properties of ewe's and cow's milk. In: Proceedings of the IDF Seminar Production and Utilization of Ewe's and Goat's Milk, Athens, Greece. 1986.

[22] CF Balthazar, TC Pimentel, LL Ferrão, CN Almada, A Santillo, M Albenzio, N Mollakhalili, AM Mortazavian, JS Nascimento, MC Silva, MQ Freitas, AS Sant'Ana, D Granato and AG Cruz. Sheep Milk: Physicochemical characteristics and relevance for functional food development. Compr. Rev. Food Sci. Food Saf. 2017; 16, 247-62.

[23] CJ Field, HH Blewett, S Procter and D Vine. Human health benefits of vaccinic acid. Appl. Physiol. Nutr. Metab. 2009; 34, 979-91.

[24] H Sales-Campos, PRD Souza1, BC Peghini, JSD Silva and CR Cardos. An overview of modulatory effects of oleic acid in health and disease. Mini-Rev. Med. Chem. 2013; 13, 201-10.

[25] P Gómez-Cortés, M Juárez and MAL Fuente. Milk fatty acids and potential health benefits: An updated vision. Trends Food Sci. Tech. 2018; 81, 1-9.

[26] E Eyal and Y Folman. The nutrition of dairy sheep in Israel. In: JG Boyazoglu and TT Treacher (Eds.). Milk production in the ewe. EAAP Publications, Roma, Italy, 1978, p. 84-93.

[27] M Coppa, A Ferlay, C Chassaing, C Agabriel, F Glasser, Y Chilliard, G Borreani, R Barcarolo, T Baars, D Kusche, OM Harstad, J Verbi č, J Goleck'y and B Martin. Prediction of bulk milk fatty acid composition based on farming practices collected through on-farm surveys. J. Dairy Sci. 2013; 96, 4197-211. 
[28] S Couvreur, C Hurtaud, C Lopez, L Delaby and JL Peyraud. The linear relationship between the proportion of fresh grass in the cow diet, milk fatty acid composition, and butter properties. J. Dairy Sci. 2006; 89, 1956-69.

[29] KJ Shingfield, M Bonnet and ND Scollan. Recent developments in altering the fatty acid composition of ruminant-derived foods. Animal 2013; 7, 132-62.

[30] A Nudda, G Battacone, OB Neto, A Cannas, AHD Francesconi, AS Atzori and G Pulina. Feeding strategies to design the fatty acid profile of sheep milk and cheese. Revista Brasileira de Zootecnia 2014; 43, 445-456.

[31] M Addis, A Cabiddu, G Pinna, M Decandia, G Piredda, A Pirisi and G Molle. Milk and cheese fatty acid composition in sheep fed Mediterranean forages with reference to conjugated linoleic acid cis9, trans-11. J. Dairy Sci. 2005; 88, 3443-54.

[32] A Cabiddu, M Decandia, M Addis, G Piredda, A Pirisi and G Molle. Managing Mediterranean pastures in order to enhance the level of beneficial fatty acids in sheep milk. Small Ruminant Res. 2005; 59, 169-80.

[33] P Gómez-Cortés, P Frutos, AR Mantecón, M Juárez, MADL Fuente and G Hervás. Effect of supplementation on grazing dairy ewes with a cereal concentrate on animal performance and milk fatty acid profile. J. Dairy Sci. 2009; 92, 3964-72.

[34] F Glasser, M Dorean, G Maxin and R Baumont. Fat and fatty acid content and composition of forage: A metaanalysis. Anim. Feed Sci. Tech. 2013; 85, 19-34. 